1996

\title{
Toward an Interparadigmatic Dialogue on Goffman
}

James J. Chriss

Cleveland State University

Follow this and additional works at: https://engagedscholarship.csuohio.edu/clsoc_crim_facpub

Part of the Criminology Commons

How does access to this work benefit you? Let us know!

\section{Repository Citation}

Chriss, James J., "Toward an Interparadigmatic Dialogue on Goffman" (1996). Sociology \& Criminology Faculty Publications. 94.

https://engagedscholarship.csuohio.edu/clsoc_crim_facpub/94

This Article is brought to you for free and open access by the Sociology \& Criminology Department at EngagedScholarship@CSU. It has been accepted for inclusion in Sociology \& Criminology Faculty Publications by an authorized administrator of EngagedScholarship@CSU. For more information, please contact library.es@csuohio.edu. 


\title{
TOWARD AN INTERPARADIGMATIC DIALOGUE ON GOFFMAN
}

\author{
JAMES J. CHRISS \\ Kansas Newman College
}

\begin{abstract}
Many observers have lamented the fact that sociology continues to fragment into a number of allegedly incompatible theoretical camps. To countervail such sectarian tendencies, I suggest that we return to the writings of key thinkers in our field-here specifically Erving Goffman-and search for those findings, observations, concepts, or analyses which have found purchase across the discipline and which seemingly defy the forces of theoretical balkanization. This interparadigmatic dialogue on Goffman can be realized only if a concerted effort is made to bring together representatives of sociology's major theory groups to discuss their possibly varying interpretations of Goffman. Problems associated with launching such a unification project are discussed.
\end{abstract}

Erving Goffman (1922-1982) certainly was, and continues to be, one of the most influential sociologists of the post-WWII era. As data from the Social Science Citation Index and elsewhere indicate, interest in Goffman remains high both across the social sciences and the humanities (e.g., see Bock 1988; Chriss 1995a; MacCannell 1983; Oromaner 1980). Secondary analyses and extensions of Goffman's work continue to proliferate unabated (e.g, see Burns 1992; Chriss 1993a, 1993b, 1995b, 1995c, in press; Drew and Wootton 1988; Hartland 1994; Manning 1992; Riggins 1990; Smith, in press; Travers 1991, 1992, 1994), and this is all the more noteworthy in the face of the ongoing sectarianism and fragmentation-what Turner (1989) has referred to as the "disintegration" - of contemporary sociology.

In light of this theoretical fragmentation, Goffman's work is central to the debate over the possibility or desirability of general sociological theory, especially with respect to the postmodern impulse which, in rejecting the grand narratives and logocentrism of Enlightenment-inspired philosophy, posits instead the loss of epistemological certitude and the "end of the subject" more generally (e.g., see

Direct all correspondence to: James J. Chriss, Sociology Department, 3100 McCormick Avenue, Kansas Newman College, Wichita, KS 67213; e-mail: chrissj@ksnewman.edu. 
Agger 1991; Clough 1992; Crook 1991; Gouldner 1970; Jameson 1991; Lyotard 1984; Seidman 1994). Years ago, for example, Alvin Gouldner (1970) wrote a scathing critique of the discipline wherein he predicted that functionalism, the then-dominant theoretical tradition, was heading toward entropy. He predicted that a new era was emerging within sociology, one that would be marked by what he called a theoretical "polycentrism," namely a situation whereby a variety of competing perspectives would battle for supremacy.

Sociology is presently going through such a period of interregnum (Wiley 1985). What is crucial to note, however, is that even with this proliferation of theoretical perspectives, each has at least an implicit theory of social action, that is, some underlying assumptions regarding the nature (or ontology) of human social behavior. Because Goffman is such a major figure in the discipline, each perspective has had to confront on some level (some more directly than others of course) the implications of Goffman's dramaturgical theory of action, especially with regard to his ideas concerning the presentation of self and the process of impression management.

Nash and Wardell (1993) are among a handful of scholars who sing the praises of the current state of theoretical diversity in sociology. The authors argue:

... interparadigmatic dialogue involves suspending epistemological judgments and granting the validity, integrity, and autonomy of diverse sociological views. Interparadigmatic dialogue also involves a continuous, reflexive discourse between different theoretical perspectives for the purpose of fostering a greater understanding of various standpoints in the human experience, and of human suffering in particular (Nash and Wardell 1993:287).

This sentiment reflects the overriding belief that sociology ought to be content with a state of theoretical accommodation wherein a plurality of perspectives peacefully coexist as each develops a unique worldview reflective of the experiences, traditions, demography, or culture of their practitioners. ${ }^{1}$ In this scenario, it is not unthinkable then to witness the proliferation of such narrowly circumscribed "perspectives" as queer theory or any of the variants of feminism (e.g., Latina, socialist, lesbian, radical, liberal), as well as any number of more traditional theories reflecting a particular methodological approach (epistemology) or subject matter (ontology).

Nash and Wardell (1993:287) see such theoretical pluralism as worthwhile in and of itself insofar as such diversity fosters "a greater understanding of various standpoints in the human experience..." In effect, whatever "truths" or explanations about the world sociology is able to claim, these must be understood as emanating from a particularistic and localized intellectual or linguistic community whose insights into and elaborations of social phenomena and experience are first and foremost contingent on the unique biographical, demographic, ideological, political, or social positions characteristic of a group of like-minded practitioners. ${ }^{2}$ From this position, no claim is made-indeed, it would be considered antithetical to the articulation of the plurality of possible standpoints if such were even attempted-that as ever greater numbers of standpoints are given voice in the 
family of social science, eventually an Archimedean point would emerge via the amalgamation of the "many" into the "one."

It is my position that the interparadigmatic dialogue championed by Nash and Wardell and others has utility only insofar as it contributes to the end, stated above, which these authors of course do not endorse, namely theoretical unification. ${ }^{3}$ I suggest that if we are ever to approach the "truth" regarding the nature of social action and whatever goes on in face-to-face interaction in general, we must dedicate ourselves to a careful and systematic analysis of how the thought of Erving Goffman has been and is being appropriated or treated by representatives of the many diverse perspectives across the social sciences and humanities which are currently in vogue.

A tentative first step toward the realization of this project was initiated by this author in August of 1994. A special session entitled "Theoretical Perspectives on Goffman" was convened at the annual meeting of the American Sociological Association held in Los Angeles. The broader aim of the project was, and is, to bring together a number of prominent thinkers representing the complete spectrum of contemporary theoretical perspectives to comment on how, and to what extent, Goffman's ideas are being utilized in their own work. The goal is to ascertain how these various perspectives or standpoints make sense of Goffman's insights concerning the exigencies of face-to-face conduct and the dramaturgy of social action and group life. Any theory concerned with explicating human social phenomena must of course deal with the ontology of social action and of social actors on some fundamental, if only tacitly articulated, level. ${ }^{4}$ Those scholars who have given some indication that they are aware of Goffman's writings or who find his insights useful for their own work are invited to comment on and appraise Goffman in light of the intellectual or theoretical community within which they practice. Eventually, after sufficient input has been gathered from each perspective, we could hope to approach a unified understanding of Goffman's primary substantive focus, namely the "interaction order" (Goffman 1983).

We have certainly seen such a proposal before. Dissatisfied with Parsons' program of general theorizing, Merton argued that, rather than putting the cart before the horse, we should instead concentrate on producing theories couched at lower levels of abstraction which would be tied more closely to specific empirical contexts. Such middle-range theories could capture the intricacies of whatever subject matter is at hand, yet still be general enough so that explanations could be provided for whole classes of similar phenomena.

Merton was not averse to general theory per se, but he felt that such an effort would be realizable only after a number of middle-range theories were produced and established within the working environs of sociology. The problem with this aspect of Merton's program, namely, the idea that the cumulation of middlerange theories would lead inexorably toward the ultimate goal of a unified theory, is that Merton never specified the mechanisms or procedures by which such a theoretical amalgamation could actually be realized (Opp 1970). Given Merton's failure in this regard, then, one might well be suspicious of my insistence that, once sufficient data is gathered from a variety of theoretical perspectives, a unified substantive understanding could be forged about the social phenomena which Goffman spent his career cataloguing and describing. 
What I am proposing here is only a start in the direction of realizing a unified theory of the social phenomena subsumed under the rubric of the interaction order, as specified by Goffman. ${ }^{5}$ The nature of theory is such that even within the same perspective or theory group, theorists will often disagree over each other's interpretations of a particular theorist's ideas or a particular substantive topic. This fact necessitates the following proposal: that representatives of each distinct theoretical perspective who have interests in or particular takes on Goffman create study groups or panels dedicated to comparing notes about their possibly varying interpretations of Goffman's ideas. I suggest this because even though interparadigmatic dialogue is crucial, not much will be gained if representatives of theory group A are at odds with representatives from B or X over basic interpretations or readings of Goffman. ${ }^{6}$ If we are to avoid the interminable squabbles over interpretation-be they substantive, methodological, or even axiologicalwhich has characterized theoretical discourse for much of the history of sociology (see Turner and Turner 1990), we must first establish an intraparadigmatic dialogue on Goffman.

Habermas's $(1984,1987)$ ongoing work on communicative action emphasizes that, in the ideal case of undistorted communication, social actors come together with the aim of reaching intersubjective understanding rather than striving for "success." The intraparadigmatic dialogue, viewed in this light, could be considered a naturalistic site for such communicative practices since the aim is to reach understanding, at least within the scope of each distinct conceptual community, about Goffman or certain aspects of his work (see also Jay 1988:34-36). Distorted communication in science is more likely to occur then at the next step, where the attempt is made to forge an interparadigmatic dialogue, since each conceptual community has vested interests in protecting its own world view, domain assumptions, and interpretations against attack from other competing perspectives (e.g., see Eisenstadt 1986). On this level, winning or success may well override the more idealistic, consensual aim of reaching understanding. I point this out merely to emphasize that I am aware of the difficult road which lies ahead in the attempt to forge an interparadigmatic, much less an intraparadigmatic, dialogue on Goffman (see Chriss 1995b).

The special session mentioned above included papers by representatives of three distinct theoretical perspectives. From neofunctionalism, Paul Colomy and J. David Brown presented "Goffman and Interactional Citizenship;" from feminist theory, Candace West offered "Goffman in Feminist Perspective;" and from phenomenology, James Ostrow presented "Spontaneous Involvement and Social Life." As George Psathas (this issue) points out, although the session from which these papers originated was titled "Theoretical Perspectives on Goffman," it would perhaps be ironic if we discussed Goffman solely on the basis of his contributions to theoretical sociology. Goffman did not consider himself a theoretical sociologist or a theorist per se, but prided himself on being able to synthesize a seemingly disparate array of observations drawn from a number of sources (e.g., game theory, ethology, sociolinguistics, semiotics, functionalism, dramatism, popular literature, and newspaper accounts).

Psathas goes on to suggest that Goffman's monographs-covering subjects as diverse as mental asylums, interaction rituals, public behavior, casino gambling, spying, spoiled identity, and radio talk-may indeed give one the impression 
that, whatever Goffman was up to, his work could be characterized as being episodic and hence not particularly amenable to systematization (e.g., see Gouldner 1970; Psathas 1980; Psathas and Waksler 1973). Although it is true that Goffman's substantive foci were diffuse and that he drew from a wide range of intellectual antecedents, there is nevertheless an underlying coherence to Goffman's approach, namely the dramaturgical metaphor which anchors understanding of the presentation of self in modern capitalist society (and beyond; see Riggins 1990). The papers by West, Ostrow, Colomy and Brown, and Psathas presented here offer situated analyses of several elements of Goffman's oeuvre, and I welcome any and all theorists, from whichever perspective, to help fill in the remaining pieces of the epistemological and ontological puzzle which is Goffman's dramaturgy.

Acknowledgments: I would like to thank William Gamson for making possible the special ASA session from which these papers are drawn. I also thank Jonathan Turner, Randall Collins, and editor Charles Hohm for their suggestions for improving earlier versions of this paper.

\section{NOTES}

1. Some would surely draw on Kuhn's (1970) work on normal science and paradigm shifts to argue that this impulse toward theoretical pluralism in sociology is merely symptomatic of the broader societal trend toward democratization and the greater inclusion of the voices of previously silenced or ignored groups (see also Colomy and Brown, this issue). As Fuller (1994:83) notes, "Kuhn's [Structure of Scientific Revolutions] helped level disciplinary hierarchies and overturn inappropriate methodological standards, thereby contributing to the climate of pluralism that (at least for the time being) continues to flourish in American universities."

2. This program is compatible with the sociology of knowledge which emphasizes the social, cultural, histori$\mathrm{cal}$, and biographical factors coinciding with or giving rise to a particular theorist's ideas. This trend toward greater emphasis on the politics of identity has given rise to a peculiar theory of the self, be it in the guise of the postmodern, decentered, fragmented, or even semiotic self (see Wiley 1994).

3. Theoretical unification through interparadigmatic dialogue is compatible in some ways with Ritzer's (1991, 1992 , 1996) program of metatheorizing, although, contrary to Nash and Wardell's assertion and my own aspirations, Ritzer's ultimate goal is not theoretical unification or cognitive consensus. As Ritzer (1996:506) explains, "On the contrary, I am arguing for more diversity through the development of an integrated paradigm to supplement extant paradigms. Like Nash and Wardell, I favor theoretical diversity."

4. What is meant exactly by the ontology of social action? I follow Wallace's (1994) recent discussion wherein he lays the groundwork for a Weberian-inspired theory of human society. I suggest that is it consistent with Goffman's view of social action and society to state, with Wallace (1994:13), that "the theory of human society... must depend first and foremost on some image of the phylogenetically 'human' individual ..." This entails specifying the psychological behavior capabilities of humans-such things as meaning, motive, conduct, and rationality-as well as their physiological behavior capabilities-natality, mortality, metabolism, motility, mutability, territoriality, and so forth. I do not claim that it is an easy task to prise open all that is tacit or unstated in Goffman's "image of man" (see Psathas 1977; Tseelon 1992a, 1992b; Williams 1988), but such foundational work is crucial nonetheless if we are ever to approach an interparadigmatic dialogue on the objects of Goffman's conceptual and theoretical attention.

5. Here I draw somewhat from Thomas Fararo's (1989) own unification profect, one whose central figure is not Goffman but Emile Durkheim.

6. For example, a feminist or postmodernist may believe that Goffman's notion of the self is decontextualized or perhaps even androcentric, in which case no substantive dialogue could take place with, say, a neofunctionalist or exchange theorist who finds nothing problematic in the ontology of Goffman's presented self.

7. I realize this proposal could be viewed quite problematically as well, insofar as one could suggest that it is no straightforward task to designate exactly which criteria establish that thinker A or B belongs to theory group 
F, Y, or Z. But if we can agree that there are indeed a number of distinct theoretical perspectives, then it follows that we can identify certain basic criteria (whether by self-identification or some other method) that characterize these specific, discreet systems of thought (e.g., see Mullins 1973).

\section{REFERENCES}

Agger, Ben. 1991. “Critical Theory, Poststructuralism, Postmodernism: Their Sociological Relevance." Annual Review of Sociology 17: 105-131.

Bock, P.K. 1988. "The Importance of Erving Goffman to Psychological Anthropology." Ethos 16: 3-20.

Burns, Tom. 1992. Erving Goffman. New York: Routledge.

Chriss, James J. 1993a. "Durkheim's Cult of the Individual as Civil Religion: Its Appropriation by Erving Goffman." Sociological Spectrum 13: 251-275.

Chriss, James J. 1993b. "Looking Back on Goffman: The Excavation Continues." Human Studies 16: 469$\rightarrow \quad 483$.

Chriss, James J. 1995a. "Testing Gouldner's Coming Crisis Thesis: On the Waxing and Waning of Intel-

$\rightarrow \quad$ lectual Influence." Pp. 33-61 in Current Perspectives in Social Theory, vol. 15, edited by B. Agger. Greenwich: JAI Press.

Chriss, James J. 1995b. "Some Thoughts on Recent Efforts to Further Systematize Goffman." Sociological Forum 10(1): 177-187.

Chriss, James J. 1995c. "Habermas, Goffman, and Communicative Action: Implications for Professional Practice." American Sociological Review 60: 545-565.

Chriss, James J. In press. "Role Distance and the Negational Self." In Goffman's Patrimony, edited by G.W.H. Smith. London: Routledge.

Clough, Patricia T. 1992. The End(s) of Ethnography: From Realism to Social Criticism. Newbury Park: Sage.

Crook, Stephen. 1991. Modern Radicalism and Its Aftermath. London: Routledge.

Drew, Paul, and Anthony Wootton. (eds.) 1988. Erving Goffman: Exploring the Interaction Order. Cambridge: Polity Press.

Eisenstadt, S.N. 1986. "Current Theoretical Developments, Research, and Controversies in Sociology." Pp. 37-49 in Advances in the Social Sciences, 1900-1980: What, Who, Where, How? edited by K.W. Deutsch, A.S. Markovits, and J. Platt. Lanham: University Press of America.

Fararo, Thomas J. 1989. "The Spirit of Unification in Sociological Theory." Sociological Theory 7(2): 175190.

Fuller, Steve. 1994. "Teaching Thomas Kuhn to Teach the Cold War Vision of Science." Contention 4(1): 81-106.

Goffman, Erving. 1983. "The Interaction Order." American Sociological Review 48: 1-17.

Gouldner, Alvin W. 1970. The Coming Crisis of Western Sociology. New York: Basic.

Habermas, Jurgen. 1984. The Theory of Communicative Action, vol. 1, translated by T. McCarthy. Boston: Beacon Press.

Habermas, Jurgen. 1987. The Theory of Communicative Action, vol. 2, translated by T. McCarthy. Boston: Beacon Press.

Hartland, N.G. 1994. "Goffman's Attitude and Social Analysis." Human Studies 17: 251-266.

Jameson, Frederic. 1991. Postmodernism, or the Cultural Logic of Late Capitalism. Durham: Duke University Press.

$\rightarrow$ Jay, Martin. 1988. "Should Intellectual History Take a Linguistic Turn? Reflections on the HabermasGadamer Debate." Pp. 17-36 in his Fin de Siecle Socialism. New York: Routledge.

Kuhn, Thomas S. 1970. The Structure of Scientific Revolutions, 2nd. ed. Chicago: University of Chicago Press.

Lyotard, Jean-Francois. 1984. The Postmodern Condition. Minneapolis: University of Minnesota Press.

MacCannell, Dean. 1983. "Erving Goffman(1922-1982)." Semiotica 45: 1-33.

Manning, Philip. 1992. Erving Goffman and Modern Sociology. Stanford: Stanford University Press.

Mullins, Nicholas C. 1973. Theories and Theory Groups in Contemporary American Sociology. New York:

$\rightarrow \quad$ Harper and Row.

Nash, Bradley, Jr., and Mark Wardell. 1993. "The Control of Sociological Theory: In Praise of the Interregnum." Sociological Inquiry 63: 276-292.

Opp, Karl-Dieter. 1970. "Theories of the Middle Range as a Strategy for the Construction of a General

$\rightarrow \quad$ Sociological Theory." Quality and Quantity 4(2): 243-253. 
Oromaner, Mark. 1980. "Erving Goffman and the Academic Community." Philosophy of the Social Sciences 10: 287-291.

Psathas, George. 1977. "Goffman's Image of Man." Humanity and Society 1: 84-94.

$\rightarrow$ Psathas, George. 1980. "Early Goffman and the Analysis of Face- to-Face Interaction in Strategic Interaction." Pp. 52-79 in The View from Goffman, edited by J. Ditton. New York: St. Martin's Press.

Psathas, George, and Frances C. Waksler. 1973. "Essential Features of Face-to-Face Interaction." Pp. 159-183 in Phenomenological Sociology, edited by G. Psathas. New York: Wiley.

Riggins, Stephen. (ed.) 1990. Beyond Goffman: Studies on Communication, Institution, and Social Interaction. Berlin: Mouton de Gruyter.

Ritzer, George. 1991. Metatheorizing in Sociology. Lexington: Lexington Books.

Ritzer, George. (ed.) 1992. Metatheorizing. Newbury Park: Sage.

Ritzer, George. 1996. Modern Sociological Theory, 4th ed. New York: McGraw-Hill.

Seidman, Steven. 1994. Contested Knowledge. Oxford: Blackwell.

Smith, Gregory W.H. (ed.) In press. Goffman's Patrimony. London: Routledge.

Travers, Andrew. 1991. "From 'Normal Appearances' to 'Simulation' in Interaction." Journal for the Theory of Social Behavior 21: 297-337.

Travers, Andrew. 1992. "The Conversion of Self in Everyday Life." Human Studies 15: 169-238.

$\rightarrow$ Travers, Andrew. 1994. "The Unrequited Self." History of the Human Sciences 7: 121-140.

Tseelon, Efrat. 1992a. "Is the Presented Self Sincere? Goffman, Impression Management and the Post$\rightarrow \quad$ modern Self." Theory, Culture \& Society 9: 115-128.

$\rightarrow$ Tseelon, Efrat. 1992b. "Self-Presentation through Appearances: A Manipulative vs. a Dramaturgical

$\rightarrow \quad$ Approach." Symbolic Interaction 15: 501-513.

Turner, Jonathan H. 1989. "The Disintegration of American Sociology." Sociological Perspectives 32: 419$\rightarrow \quad 433$.

Turner, Stephen P., and Jonathan H. Turner. 1990. The Impossible Science. Newbury Park: Sage.

Wallace, Walter L. 1994. A Weberian Theory of Human Society. New Brunswick: Rutgers University Press. Wiley, Norbert. 1985. "The Current Interregnum in American Sociology." Social Research 52: 179-207.

Wiley, Norbert. 1994. The Semiotic Self. Chicago: University of Chicago Press.

Williams, Robin. 1988. “Understanding Goffman's Method." Pp. 64-88 in Erving Goffman: Exploring the Interaction Order, edited by P. Drew and A. Wootton. Cambridge: Polity Press. 